\title{
Tangible Experiences of Grace: A Qualitative Investigation of Divine Grace in Roman Catholics
}

\author{
Hunter B. Harwood ${ }^{1} \mathbb{D} \cdot$ M. Elizabeth Lewis Hall ${ }^{1}$ D $\cdot$ Keith J. Edwards $^{1}$ (D) . \\ Peter C. Hill ${ }^{1}$ iD
}

Accepted: 20 September 2021 /Published online: 18 October 2021

(c) The Author(s), under exclusive licence to Springer Science+Business Media, LLC, part of Springer Nature 2021

\begin{abstract}
According to Catholic theology, God offers a gift of love, known as divine grace, to all of humanity. This gift of divine grace is the gift of redemption and forgiveness of sins from God that is offered to everyone who decides to acknowledge and accept it. Grace is central to the lived experience of many Christians. This qualitative study examined how Catholics perceive and experience divine grace using interviews that assessed perceptions of divine grace in 29 practicing adult Catholics. A grounded theory analysis resulted in themes indicating that these Catholics view God's divine grace as a tangible gift that is undeserved though continuously offered. The participants' experience of God's grace is not just an abstract theological concept but an embodied aspect of religious life with which believers can interact in many powerful ways. Three characteristics of God's divine grace (i.e., salvific grace, cooperation through free will, primacy of conscience and the afterlife) and three mechanisms to experiencing God's grace (i.e., sacraments, prayer and meditation, saints) are presented.
\end{abstract}

Keywords Grace $\cdot$ Catholic $\cdot$ Spirituality $\cdot$ Qualitative $\cdot$ Grounded theory

While research in the psychology of religion has made substantial progress in investigating the religious life of individuals, one theological concept that is central to many religious groups, grace, has received relatively little attention. Emmons et al. (2017) noted that grace is "the gift of acceptance given unconditionally and voluntarily to an undeserving person by an unobligated giver... grace reflects a vital psychological need held by all people" (p. 276). Recently, grace has been investigated in a handful of quantitative studies in conservative Protestant populations (Bufford et al., 2015, 2017; Judd et al., 2020). However, to date there have been no quantitative or qualitative studies that have focused explicitly on the aspects of how Catholics uniquely experience God's divine grace, which is an ongoing and prominent aspect of Catholic life.

The Catholic theology of divine grace is distinct from Protestant theology as sacraments (e.g., the Eucharist, confession) actively embody God's grace and good works

Hunter B. Harwood

hunter.b.harwood@biola.edu

1 Rosemead School of Psychology, Biola University, 13800 Biola Ave, La Mirada, CA 90639, USA 
assist the believer to participate in divine grace. Thus, it is possible that Protestants may experience divine grace more subjectively while Catholics may experience divine grace more tangibly as sacraments and good works allow grace to be participated in throughout the lifespan (McHugh \& Callan, 1923). In this study, the focus is on Catholics' experience of divine grace as the gift of love through divine acceptance. As suggested by Emmons et al. (2017), the current study employed a qualitative methodology based on openended interviews to explore how Catholics think about, experience, and are impacted by divine grace. The literature review first examines the Catholic theology of divine grace, focusing on the process of justification and how grace is manifested through the sacraments and good works. Next, a review of psychological research on the topic of grace is presented.

\section{Catholic theology of divine grace}

Historic Christian teachings about grace are similar across conservative segments of Christianity. In the Bible, especially in the writings of Paul, the concept of grace is described using the Greek word $\chi \alpha \alpha_{1} 1 \varsigma$, which translates as favor or gift (Barclay, 2015). From a theological perspective, this gift of divine grace is the gift of forgiveness of sins from God that is offered to everyone who decides to accept it (Emmons et al., 2017; McMinn et al., 2006). This notion of grace comes out of God's abundance of love for humanity, and it is not based on any merit in the individual. Humanity did not do anything to earn grace, although it is expected that once the gift is accepted there will be ongoing obligations to fulfill (Barclay, 2015). Divine grace was made possible because God sent Jesus Christ to earth to save humanity. Through Jesus' crucifixion and subsequent resurrection, forgiveness of sins was achieved so that all could have the opportunity for salvation. However, different segments of Christianity also differ in some teachings related to grace. Here, we cover three distinctive aspects of Catholic teachings regarding grace: sacraments, justification, and good works.

\section{Grace through sacraments}

To deepen believers' experience of grace and relationship with God, Catholics engage in sacraments. Sacraments are ways in which individuals can participate in God's grace. There are seven recognized sacraments that make the grace of God accessible: baptism, Eucharist, confirmation, reconciliation, anointing of the sick, marriage, and holy orders (Godzieba, 2008). The first sacrament partaken of is baptism. Baptism provides salvation and opens the door to the other sacraments. However, even after baptism, humanity continues to be sinful. Believers must continue to be transformed into the likeness of Jesus through engaging in the remaining sacraments and in actions such as praying the rosary, keeping the company of saints, and obeying the pope (Stjerna, 2015). A study by McKay et al. (2013) demonstrated that participating in confession promotes prosocial behavior. In their study, Catholic participants were asked to recall committing and repenting of a past sin. Results demonstrated that imagining forgiveness of their sins increased the pro-social behavior of donating to the Catholic church. The effect was stronger for individuals who believed in divine judgment and those who engaged in spiritual practices. 


\section{Grace and justification}

In response to the Protestant Reformation, the Roman Catholic Church held the Council of Trent, which rejected the Protestant idea of faith alone and endorsed a "both/and" view of grace and works. The both/and view of grace holds that justification is to be achieved through both faith and works (Council of Trent, 2019). However, this does not mean that Catholics believe that individuals need to complete works to be forgiven. Rather, one is justified or considered to be "saved" once one is baptized. Yet, this justification is not static as believers are continually transformed throughout their lives. While the sin of humanity was paid for by the blood of Christ, humans are still incapable of turning to God for deliverance alone because of their sinful nature (Catholic Church, 2000). Humans must "cooperate" and allow God to divinely intervene and justify them through God's grace (Vidovic, 2019).

\section{Good works through grace}

Works are ways in which believers cooperate with God (Washburn, 2015). According to Pope Benedict XVI, one is able to engage in good works after God enters the soul through

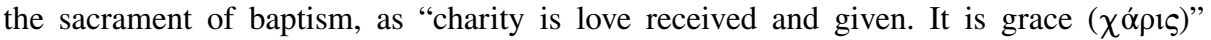
(McBrien, 1980, p. 991). Through justification and the process of sanctification, humanity is able to live in God's divine grace and produce good works that glorify God. According to Catholic tradition, engaging in good works will allow the believer to be reformed into the perfect image of Jesus Christ (Fuliga, 2009). There are many examples of good works in which believers should engage, as demonstrated and proclaimed by Jesus Christ throughout the New Testament. For instance, believers are called to help those in need by clothing, feeding, and visiting them (Matthew 25:31-46).

Qualitative research has been conducted to better understand how God's grace plays a role in charity. A qualitative study completed by Warner et al. (2015) examined the associations between making a charitable donation (i.e., to either a religious or secular group) and duty to God, community expectations, and perceptions of God's grace among Catholic parish members. Overall, it was revealed in the essays and interviews that "God's grace and deservingness prompted thoughts of charity and that duty to God did not" (p. 204). Participants did not consider helping others a duty to God or a requirement of the faith; rather, they considered it a choice to "live as God tells them" (p. 200).

\section{Quantitative studies related to divine grace}

Psychologists cannot directly measure God's divine grace, although it is possible for researchers to measure human experiences and perceptions about the divine. Researchers have attempted to quantify these experiences through developing self-report instruments such as the Grace Scale (GS; Payton et al., 2000; Spradlin, 2002), Richmont Grace Scale (RGS; Blackburn et al., 2012; Sisemore et al., 2011; Watson et al., 2011), The Amazing Grace Scale (TAGS; Bassett and the Roberts Wesleyan Psychology Research Group, 2013), and Dimensions of Grace Scale (Bufford et al., 2017).

The quantitative studies that have examined grace thus far suggest that grace can assist believers in fighting against negative mental health symptoms such as religious and existential distress, internalized shame, perfectionism, anxiety, and depression (Bufford et al., 2015, 2017; Judd et al., 2020), as well as fear of sin and punishment from God (Judd et al., 2020). However, these measures broadly define grace in a mostly relational human 
dynamic (i.e., grace to self and others) in non-Catholic populations and have operationalized grace from a primarily Protestant framework. Consequently, it is unclear whether these findings would be replicated in Catholic samples.

Two qualitative studies have been conducted that emphasize grace as divine assistance. Bronte and Wade (2012) asked 25 people ages 22 to 66 to define and describe grace, discuss their thoughts and beliefs about the change in their life, what happened before and during the change, and what convinced them to believe that the grace came from a divine being such as God. Altogether, the experiences of grace mainly clustered into three categories: presenting problems, increased self-efficacy, and fulfilled needs. Overall, the participants expressed that grace made them feel loved and enlivened by the divine and that it allowed them to change by letting go of undesirable preconceived ideas, conditions, and actions.

Further, Sytsma et al. (2018) completed a qualitative study that examined the impact of spiritual life review and legacy document formation with five elderly people suffering from advanced diseases. Four common themes were identified across the interviews: community, strength, inspiration, and spirituality providing comfort. One of the participants was an 82-year-old Catholic man with mild cognitive impairments and a diagnosis of coronary artery disease. He reported that his religion was a source of comfort for him and that he felt he could take all troubling experiences and thoughts to God and "then let [them] go." Throughout his life, he struggled with drinking and chain smoking, though after asking for God's assistance, he claimed, "God gave me the grace to change."

Studies such as these suggest that divine grace plays an important role in one's spiritual well-being. Individuals express that God's grace allows them to experience positive life change (e.g., break addictions), acquire emotional experiences (e.g., feel love and enlivenment), and have more positive experiences with others (Bronte \& Wade, 2012; Sytsma et al., 2018). However, these studies do not focus explicitly on the Catholic population and do not speak to the unique aspects of how Catholics possibly experience God's divine grace (e.g., confession, Eucharist, good works).

\section{Present study}

To date, no studies have focused explicitly on the unique aspects of how Catholics experience God's divine grace. It is important to explore the construct of divine grace as it is an ongoing aspect of the Catholic life that is distinct in some ways from Protestant conceptions of grace. The purpose of this qualitative study was to address the following research questions: (a) How do Catholic individuals describe, perceive, and experience God's divine grace? (b) What are the ways in which Catholics experience God's divine grace in religious community and spiritual practices?

\section{Method}

\section{Participants}

After receiving ethical approval from the institutional human rights in research committee, 29 adult participants were recruited for this study. Recruitment consisted of advertising the study by word of mouth in four states (i.e., Oklahoma, California, Texas, South Carolina) and convenience sampling in local universities and Catholic churches 
in the Los Angeles and Orange County (California) areas using announcements and emails. The primary researcher recruited in these four states because she had personal and academic connections to assist with recruiting and she wanted to diversify the sample. The researcher also directly emailed individuals who were recommended as participants (e.g., individuals were recommended by various faculty at Biola University) and posted on social media platforms (e.g., Facebook) to seek volunteers. Participants were compensated with $\$ 50$ Visa gift cards.

Twelve participants $(41.38 \%)$ were male, and 17 were female $(58.62 \%)$. The participants ranged in age from 18 to 77 years of age $(M=39, S D=17.54)$. Sixteen participants self-identified as White (55.17\%), 10 as Hispanic or Latino (34.48\%), and three as biracial or multiracial (10.34\%). Twenty-seven $(93.1 \%)$ reported attending mass once weekly, one $(3.45 \%)$ reported going twice a week, and one $(3.45 \%)$ reported attending daily. One reported attending confession twice a week $(3.45 \%)$, one attended weekly $(3.45 \%)$, seven attended once monthly (24.14\%), two attended semimonthly or twice monthly (6.9\%), five attended bimonthly or every two months (17.24\%), two attended quarterly (6.9\%), eight attended biannually (27.6\%), and three attended annually (10.34).

\section{Procedure}

A semistructured interview was developed for 60-90-min interviews to address the research questions. The interview questions examined the participants' experience, explicit/implicit views of God, perceptions of God's view of the self, spiritual struggles, spiritual practices, and understanding of saving, accepting, teleology/sanctifying, and common grace. The questions were open-ended and were revised in subsequent interviews to reach theoretical saturation (Charmaz, 2014). For instance, one interview prompt was changed from "Catholic theologians often mention the concept of salvation by grace and works" to "Catholic theologians often mention the concept of grace and its relationship with good works." This amendment was made as Catholic participants in the earlier interviews expressed the belief that salvation is not achieved through works.

Due to the subjective nature of qualitative research, the primary researcher provided a reflexive statement that identified personal information that might have potentially biased the analytic process (Fischer, 2009; Levitt et al., 2018). She identifies as a 26-year-old White Protestant female who was raised in a Christian household. Throughout her life, she has been involved in the Protestant community, though she has also studied Catholic theology academically and knows many individuals who identify with the Catholic tradition.

Furthermore, the primary researcher engaged in memo writing that included the researcher's reactions, questions, and ideas throughout the coding process to maintain fidelity (Levitt et al., 2018). Also, six interviews were double-coded to reduce subjective bias (Landis \& Koch, 1977). The research assistant who conducted the double-coding was a White Protestant female in her early $30 \mathrm{~s}$ pursuing a $\mathrm{Ph} . \mathrm{D}$. in clinical psychology who had previous experience coding interviews for qualitative psychological research. There was substantial agreement between the two coders $(k=.7 ; 97.86 \%$ agreement). Lastly, a member check that included summaries of major findings was completed to validate and ensure that the researcher reflected on the participants' experiences accurately and objectively (Birt et al., 2016). The member check did not result in any changes to the analysis. 


\section{Data analysis}

The interviews were analyzed using Charmaz (2014) grounded theory. Once all interviews were transcribed, initial open coding was completed, analyzing each word on every line. This step categorized features of the participants' faith and life journeys and encapsulated each participant's experience into overarching themes (e.g., spiritual experiences and practices). Following this, axial coding was completed. This step allowed the primary researcher to break down core themes (e.g., characteristics of divine grace, mechanisms for experiencing God's grace) and identify relationships between categories and subcategories (e.g., salvific grace, grace through sacraments). Open coding and axial coding were completed simultaneously, chunking the data into categories while the interviews were read several times through. Through open and axial coding, the themes were refined, forming interconnections. Next, the primary researcher developed a rough draft of the theory regarding how Catholics experience and perceive God's divine grace. The primary researcher consulted with professionals associated with the project to fine-tune the theory. Lastly, selective coding was completed to review the core categories and themes to produce a conclusive and cohesive theory (e.g., tangible grace).

\section{Results}

The interviews gave insight into how the Catholics in this study experienced God's divine grace and their understanding that the offer of grace should be returned with obedience after being accepted. The overarching meta-theme identified in this study was tangible grace. The grounded theory that emerged suggests that the participants' experience of God's grace was not just as an abstract or mysterious theological concept but a material, embodied, and concrete aspect of religious life with which believers could interact in many powerful ways. The tangibility of God's grace makes Catholic experiences and perceptions of divine grace distinct from Protestants in that many Catholic religious rituals and practices (e.g., the Eucharist, confession) provide a strong literal and physical sense of connection with God.

While the analysis resulted in a number of themes that are common across Christian groups (e.g., grace as a gift, continuous grace, common grace), here we focus on the ones that are most distinctive to the Catholic experience. Consequently, in this results section various characteristics of divine grace (i.e., salvific grace, cooperation through free will, primacy of conscience and the afterlife) are presented. Next, several mechanisms for experiencing God's grace (i.e., sacraments, prayer and meditation, and saints) are discussed.

\section{Characteristics of divine grace}

Throughout the interviews, the participants described many characteristics of God's divine grace, demonstrating the complexity of the concept. In this section of the results, three descriptors of God's grace are discussed: salvific grace, cooperation through free will, and primacy of conscience.

Salvific grace Twenty-eight participants discussed the salvific nature of God's grace. Participants described throughout the interviews the belief that humanity is offered grace through God's love and Jesus' crucifixion and subsequent resurrection. One woman 
reflected on the salvific qualities of God's grace, accentuating God's initiative and mercy on humanity:

By His grace, I am saved, and even if I'm that one lost sheep, He always goes to look for me. . . I'm thinking back to the Prodigal Son story, the father's grace saved the son before he even asked for redemption. . . . I think that's what saved by grace is, that God's love for us is so immense ... no matter what, He will love us.

Likewise, a male participant described how humans are in a constant state of grace:

At the beginning of John, it says because of Him we received grace in place of grace ... we are in a constant state of grace, everything that we see is because of God's grace. . . Because of His grace we receive that forgiveness no matter what, even though we turn away [from] His grace. . . . We still have that option to turn back to Him to be saved through His grace because of His infallible divine mercy.

This man's words suggest that humans are always in a state of grace unless they reject God. Nevertheless, people are always given the choice to change their minds and receive salvation again.

Moreover, a few participants described salvific grace as being associated with God's love for humanity. For example, one man expressed that he feels that God offers him salvation and love through divine grace:

It's not really about my credits, it's about God's grace. . . . It's not something that I deserve, it's not something that I've sort of earned . . . salvation I think and just His love overall, I think it's something that He gives me regardless.

Similarly, one female participant described how obtaining salvific grace is about being open to God's love:

If I don't follow God, if I'm not open to His love, I won't be saved. . . . It's not of my own merit that I am saved. . . . God gives me, gives us, the grace to be saved. . . I know that everything that I need is in Christ. . . . I think God gives us the avenue by which we can be saved.

Cooperation through free will Twenty-five participants discussed the importance of continuously cooperating with God's grace through free will. As previously mentioned, the first sacrament partaken of is usually baptism. According to the Catholic tradition, baptism provides an individual salvation; however, humanity continues to be broken and sinful even after baptism. Consequently, believers must continue to be transformed through the process of sanctification and must continuously interact in God's grace.

One male participant described how Catholics believed that they are justified, or cleansed from sin, through baptismal regeneration, though one must continue to be transformed through engaging in good works:

Salvation is a process. ... We are all saved by the grace of baptism. . . Throughout my life, I can do what is right or what is wrong, and God allows people to do wrong things or good things, but He infuses grace in person so we can do good works, and it's His own work, His own gracious works that are acting through us. That's what we mean by salvation by grace and justification by works. 
This participant's words align with the "both/and" view of grace from the Council of Trent, which stated that justification was achieved through both faith and works (Council of Trent, 2019).

These Catholic participants emphasized that a part of engaging in a "both/and" view of grace is actively cooperating out of one's free will. One female participant stated that her faith has to include her statement of faith and her free will's cooperation with God:

My faith in Christ is essential to my salvation, and this faith can't just be an utterance "Jesus is my Lord and Savior," that's not enough, my faith needs to produce fruits, which are good works, and me using my free will to cooperate with Him. Anything I do is not through my own merit; it's through my free will's cooperation with God's original intention for me and cooperation with His will.

Similarly, a male participant expressed the belief that humans are meant to act in obedience to God's grace, although God never forces this because God gave humans free will to make individual choices:

We have free will, and because He loves us and because we're not robots, we have the choice to love Him. . . . It talks about how your works in the Bible are as filthy rags to God, that means you can't do anything without the will of God. . . . Anything good cannot come from you; it has to come through God's will. . . . I'm reminded of Paul talking about working out your salvation with fear and trembling. ... Your life is just a series of moments, of choices all together, and at any given time I could make a choice to go to the right or to the left or go straight . . . where I have that decision-free will.

This man referenced Paul's words in Philippians 2:12 to communicate the importance of humans needing to act in obedience to God's grace that is provided.

One female participant described how cooperating with grace is not an obligation but a way of being in a relationship with God:

Grace comes first and then works as a result of that ... it's mostly tied to kind of James's book in the Bible where it talks about faith without works is dead . . . through grace, we are able to then thus work out our faith. . . I don't see it as an obligation but more of God's grace working in me that's allowing me to do these things as an act of love for Him. It's more of a relationship . . . not like me as a soldier taking commands from the commander but more so of me being in a loving relationship and choosing to do these things for God, and not because it's changing His status of me or the way that He thinks about me, but it's more so my way of showing God that I appreciate the grace that He's showing me every day, but it is also His grace that's allowing me to share this to say that to Him anyway, so it really is this beautiful thing where God gives you the ability to show Him that you love Him, but it's also your willingness to be open to receiving that grace.

This woman referenced James 2:14-26 to argue that works, not faith alone, justify humans. She argued that humans must daily choose, using their free will, to prioritize God's grace. Cooperating with God's grace has personally allowed her to build a loving relationship with God. One male participant reflected that God is always seeking out this relationship with humans, regardless of what they have done: 
He's always seeking you with His grace, always . . . He has called me to reach out many times to homeless people, and what Jesus has said is you don't have to reach out to them physically; you can reach out to them through prayer.

In his reflection, this participant communicated that humans are called to cooperate with God's grace by engaging in this relationship with God and others who need prayer, such as people currently living in homelessness. Free will is implied in this reflection as he describes humans needing to reach out to God to have a relationship, not God forcing humans to have a relationship with God.

Similarly, a woman suggested that a part of cooperating with God's grace is working toward justice in the world by volunteering personal time and material goods:

I can't possibly recognize how much I've been given without feeling a profound and inescapable obligation to return and to pass on ... whether that's material giving or volunteering, or time, but also to accompany people to be present to them, to build community, to be working for justice in the world. . . . I see grace as fundamentally almost like a verb rather than a noun, of something that is generative, that is life-giving, that isn't static, that is dynamic, that is always giving, and renewing, and calling forth a response.

According to this woman, grace is a verb that calls for action. She suggests that it is an obligation and duty for believers to cooperate with grace once accepted.

Another female participant suggested that believers can cooperate with God's grace by listening to God, being mindful, and opening their hearts:

It's up to me to listen, to be mindful, and to open my heart so that $\mathrm{He}$ can give me whatever graces that He wants me to have. . . We talk about the works of mercy - being kind ... give food to the hungry, drink to the poor, clothing. . . . We have to be charitable, and kind and caring, and loving, even if it's hard. . . . I'm not going to be saved by my works, I'm going to be saved by God's grace, and that's His decision.

Generally, she argued that Catholics are meant to serve others through tangible works of mercy and to demonstrate love. Overall, she communicated that believers are saved by God's grace, although it is also a believer's job to engage in whatever works God desires and to actively use their free will to listen and be mindful of God's daily offer of graces.

Primacy of conscience and the afterlife Nine participants explicitly expressed how grace plays a role in going to heaven or hell and what Catholic doctrine says about eternal salvation for individuals who are not Catholic. A few participants utilized the concept "primacy of conscience" to describe what Catholics teach about salvation for those outside of the Catholic tradition. One female participant explained how she understands the term primacy of conscience and its connection to the afterlife:

The theology of the primacy of conscience, which in the catechism states God takes everything into account when He considers His creation. He looks at their circumstances. He looks at their illness, if they have hard experiences, if they'd been abused and turned away from the church, He sees those things, and He will not hold them against us in His infinite mercy. . . . An atheist who made moral decisions based on their primacy of conscience-God sees that as good. 
Similarly, another female participant expressed that if people make moral decisions, they can achieve salvation, even if they have denounced their faith or never heard of Catholicism:

The whole goal, if you're Catholic, is to get to heaven. ... His grace makes it eventually, so we can meet Him in heaven. There are steps, like purgatory, just so that we are ready to receive God. . . People who have no way of knowing what Catholicism is or they have a hard time knowing who God is, I think that they can for sure find God's grace if they have a sense that there's a higher power and they do everything that they can to be good to others. . . I think even if someone denounces faith God would still be there.

One woman expanded on the idea of people making moral decisions, though she highlighted how God's grace can protect people from going to hell:

As a faith, we teach that salvation is through Jesus alone, the truest way to salvation, and the truest way to understand God's grace is through the Catholic church. But we also firmly believe that God is merciful. ... . One of the things I love about the Catholic faith is that we will never say anyone is in hell ... we believe that in the end, the final judgment. that God has a way. . . . Through His sacrifice, it opens the gates, and it is His grace that allows us to enter, but you know if there are barriers to that, God is understanding of that.

Overall, these participants argued that as long as people are generally making moral decisions, people can achieve grace and heaven as God offers grace freely to all, and God takes individual circumstances into account when determining where one should spend the afterlife.

\section{Mechanisms for experiencing God's grace}

Throughout the interviews, the participants also described various mechanisms for experiencing God's divine grace. Three mechanisms for participating in God's divine grace are described: sacraments, prayer and meditation, and saints.

Grace through sacraments Twenty-eight of the participants discussed experiencing divine grace tangibly through engaging in sacraments. The two sacraments that were discussed the most in the interviews were the Eucharist and confession. These two religious sacraments seemed to be especially helpful as they directly engage one's senses (e.g., touch, taste, sound); they allow grace to be embodied. The Eucharist especially interacts with one's senses in an intimate way as it is meant to be consumed. One young female participant described the intimacy of the Eucharist and how it is not taken solely as a symbol but as Jesus' literal flesh and blood:

There is a term called "transubstantiation" where it is no longer that piece of bread, but it is literally Jesus Christ's flesh. . . . We believe that it transforms into Jesus Christ's flesh once it's consecrated by a priest. When we receive it, it is a very intimate moment where we are actually uniting our actual bodies with Christ's body. . . . We very much take that passage literally where Jesus Christ says, "he who eats of my flesh," he desires that we take that very literally. 
Thus, ingesting the Eucharist allows one to literally embody God's divine grace.

One woman described how partaking in the sacrament of the Eucharist helps believers become part of the body of Christ:

We believe that it's literally the body and blood of Christ. Christ's flesh enters into us and it gives us some real strengths, and we become part of the body of Christ. ... Being able to partake in salvation history like through the Mass, it's such a grace ... it's such a stabilizing thing for me.

This woman feels that engaging in the Eucharist is a grace as it allows her to be strengthened and stabilized. By consuming the host, the church as a whole is able to come together and become part of the literal body of Christ.

Another female participant emphasized the Eucharist and its ability to help her personally feel God's divine grace:

It's Jesus himself and the fact that he's willing to be in that humble state hidden in the host and give it to me, it's just so powerful. I feel His grace really strongly in that moment because it's so tangible. I'll have the host in my mouth, and I imagine that it's like flesh. ... I look up at the crucifix and think about how that was for me and everybody.

Consuming the Eucharist allows this woman to be reminded of Christ's sacrifice on the cross and consequently the grace that she believes is offered to her.

Further, the sacrament of reconciliation, also known as confession, was frequently described by participants. One woman talked about the process of confession and how one is able to achieve forgiveness through the sacrament:

Catholics believe that when the priest is confessing you, he is no longer himself, but he is Jesus Christ himself as the sole confessor. . . . I think that is a very intimate moment where I can come completely vulnerable to him and approach him . . the sacrament is very important and very powerful, it's allowing us to really be able to conceptualize what it would be like to actually come to Jesus Christ himself and to be vulnerable and allow him even into the areas that we try to hide on a daily basis and to be able to allow him to come to transform those areas as well.

This form of direct communication allows God's grace to be embodied and tangible for the penitent. Due to God's divine grace being embodied in confession, this woman has been able to allow God to transform her life.

A female participant explained the experience of confession in a poem she wrote entitled, "Upward Spiral":

It's this idea that I'm in the state of grace and then I start sinning-I'm down, I'm lower, I'm less holy, and then if I am at that bottom point I go to confession and it springs me up to even higher than I was before in my holiness, and then it repeats, and so it's like every time I get a little bit higher after I fail and then repent and get closer to God, and that spring, that catalyst is Christ's grace. . . . It's just a gift. The line in the poem is, "Springs me up to a place that I do not deserve," and ultimately the idea is what God cares about is our appearance, not our perfection.

Her poetic words give a visual for how believers are in a constant state of grace, though faith has its up and downs. Through confession, she feels that she is able to get closer to God when she is feeling down through God's catalyst, grace. 
One female specifically made the connection between confession and grace, discussing how it assists her in relieving her burdens:

Confession, that's one way that we experience God's grace really as much as we want. ... I've had experiences where I just felt really burdened by something because of something I've done, or something just weighing on my heart and bring that to confession and receiving God's mercies, it can be overwhelming sometimes because I think I'm very undeserving of it. . . As Catholics, we believe that in confession the slate of our sins is wiped clean. and that's just incredible, a grace.

A male participant expressed a similar sentiment about feeling a difference before and after confession: "Every time I go to confession, nothing is required of me except to repent, to be restored to this relationship of grace with God.... It's a huge difference before and after. I feel that the guilt is removed, it really makes a difference in how you approach life."

Prayer and meditation Twenty-six participants discussed prayer and/or meditation. The form of prayer discussed most often was contemplative prayer, such as the examination of conscience. One woman reflected on her experience of engaging in the examen:

You go over your day and you say what you are grateful for, where you responded to God, and where you hadn't responded to God's love, and you make a resolution. . . . The Catholic tradition is always inviting us into deeper contemplative prayer . . it is how I interpret grace in the sense of God giving us His grace versus us reaching for it.

A young man also talked about the importance of the examen in his spiritual life and how it assists him in engaging in self-reflection:

... like in the examen, I've journaled at times and I'll be praying and then I'll come to something that I'll stick to or that like really sticks out in my mind and I'll write it down and then I can start praying over that one idea more, almost like a little Lectio Divina. . . . It just helps me come to a more receptive and listening attitude to hear what's trying to be said to me about these topics [grace] and reveal something to me. Why did these stand out? Or, in this situation where you weren't the best version of yourself, what really happened there?

One man described what Lectio Divina is to him and how it is related to God's grace:

Whatever God calls you to focus on, you repeat that in your heart . . it's interesting because sometimes I'll just start doing it subconsciously. . . . I look throughout my day and God's grace has allowed me to reflect on that and it draws me closer to Him.

For others, engaging in more visual forms of prayer can be helpful in connecting to God's grace. For instance, individuals can engage in the Stations of the Cross, a 14-step Catholic devotion that honors and observes Jesus' last day on Earth utilizing small icons or images, starting with Jesus' condemnation (Catholic Online, n.d.). One man described this religious ritual in his interview:

It is 14 stations of Christ's crucifixion, and you pause at each one where the women meet Him and where one man has helped carry the cross and He's crowned with his thorns ... you say prayers ... you can kind of feel good based on those and come out feeling that you're full of grace or you have received grace. 
Another form of visual prayer that is a part of Ignatian spirituality is composition of place. One female participant described this type of imaginative prayer and how it had helped her in her prayer journey:

You read a Scripture passage and usually read it a couple of times, and then you imagine yourself in the scene. ... Sometimes you notice things or imagine things that you wouldn't necessarily expect, and also sometimes the scene doesn't end up playing out the way it does in the Scripture. . . Entering into a place of imagination and allowing things just to unfold rather than thinking about them, or like meditating on the meaning of a particular passage or Scripture but just sort of allowing things to unfold and to experience them, [be] present to them, is really a wonderful way of praying that I think can be really profound. . . I do try to imagine all the meanings and possibilities, and so to have something like "I didn't think about that before" or "I experienced that in a different way than I expected" has been really great.

Moreover, in the Catholic tradition the majority of prayers are to God; however, Jesus' mother, Mary, is also an important figure in regard to prayer. Many Catholics ask Mary for intercession in their prayer lives. By asking for Mary's intercession, believers can request assistance in forgiveness, an important component of grace. One woman recited and discussed the Hail Mary prayer that comes from Luke 1:28-42:

"Hail Mary, full of grace, the Lord is with you. Blessed are you amongst all women and blessed is the fruits of your womb Jesus. Holy Mary, Mother of God" . . . "pray for us now and at the hour of our death."

Grace experienced through saints Fifteen participants discussed how they tangibly experienced God's divine grace through the saints. Generally, the participants expressed respect for the saints and conveyed gratitude for the ways in which saints modeled how to live in God's grace. For instance, one woman described how saints are good examples for those in the Catholic church:

The saints are a very good example of the things that we're able to do through God's grace ... they were never perfect individuals, but they were fallen humans who were able to allow God's grace to work to the fullest extent in their own lives. ... They had sinned very heavily in their lives but still were able to come to a point where they were able to experience God's grace in their lives.

The participants were able to tangibly experience God's grace through the saints as they connected to their humanity. For example, one man described how he could identify with St. Teresa of Calcutta (i.e., Mother Teresa):

Saints are so important to me because I can connect to their humanity, like when Mother Teresa and those letters came out where it said like she doubted sometimes that God was with her and she was frustrated with God. . . . Mother Teresa did everything she did and struggled. . . . I pray to Mother Teresa, or I pray to Jesus, kind of like a friend, like, "I'm in it now, and if you're able to be here with me it would help." So, I see God kind of like disseminating through people and being with me through different people. 
It was evident that the teachings and experiences of the saints were influential to the personal and spiritual aspects of the participants. One woman described how Saint Teresa's teachings helped her understand God's grace and divine mercy:

Saint Teresa also has this little line that says, "Do all things with great love." . . . It is not up to us to make change; it is not up to us to be perfect because we never will be. ... When I am down on myself . . I have been told and believe that God is more concerned with my attempt, with the condition of my heart. That's the kind of father $\mathrm{He}$ is, so if that's the case, obviously His grace is going to do the rest.

Further, the saint that was discussed the most throughout the interviews was St. Faustina Kowalska, a Polish nun and an apostle of Divine Mercy. One woman described in detail Lady Faustina's significance in the Catholic church:

She experienced a lot of intimate episodes with Jesus Christ, a lot of moments of just feeling pure love and just grace. ... He came to her in a vision. ... He wanted to let her know to pray a prayer every time at three o'clock. . . Y You say, "Eternal Father, I offer you the body, blood, soul, and divinity of our Lord Jesus Christ in atonement for our sins and those of the whole world" ... and then you say, "For the sake of His sorrowful passion have mercy on us and on the whole world." and you say that 10 times.

Later, she went on to discuss how St. Faustina's prayer personally helps her experience grace:

I think that's a great example of God's grace and mercy falling on everyone, not just when we pray this prayer. . . . Sometimes I fall short of other prayers that I do, but I am very faithful to that particular prayer because it does really orient my heart towards God's grace and the richness of God's grace if we're all really aware of it and open to receiving it.

The Divine Mercy Chaplet helps her participate in God's grace because it reminds her of God's vulnerability and Jesus' sacrifice on the cross.

\section{Discussion}

The study aimed to develop a more robust conceptual framework surrounding the experience of divine grace as it is an ongoing aspect of Catholic life. The findings must be interpreted with the limitations noted below in mind. Nonetheless, the interviews reiterated the importance of grace in the lives of Catholics. The meta-theme in this study was tangible grace. The results suggested that these Catholics tangibly experience and perceive God's grace. For these participants, grace is not just an abstract theological concept but a concrete element that can be embodied and interacted with powerfully. The meta-theme of tangibility makes the Catholic experience of grace distinct from that of Protestants. The religious rituals and practices of Catholicism (e.g., the Eucharist, confession, saints, good works) make God's grace tangible and embodied, whereas grace in Protestant traditions is often more subjective. Having a tangible means to access God's grace was experienced as valuable to the participants as they perceived it to allow for a more intimate connection with God. These powerful means of intimacy (e.g., the Eucharist) can be important for many 
Catholics and play a prominent role in Catholics' spiritual identity and personal relationship with God.

First, various characteristics of divine grace (i.e., salvific grace, cooperation through free will, primacy of conscience) were identified. Participants described God's grace as a gift to all humanity that provides salvation. This grace was described as needing to be cooperated with through humanity's free will (e.g., engaging in good works). Generally, these participants argued that as long as people are making moral decisions, people can achieve grace and an afterlife in heaven because of the Catholic belief of the primacy of conscience. Second, three mechanisms for experiencing God's grace (i.e., sacraments, prayer and meditation, and saints) were indicated. Participants emphasized the importance of the Eucharist and confession, engaging in contemplative prayer (e.g., examen, Lectio Divina), and looking to saints as models of God's grace.

\section{Comparison to existing literature}

Divine grace is a central theological concept that has received relatively little attention in the psychological literature. Several studies over recent years have attempted to measure self-report experiences of God's grace in the context of Christianity (Bronte \& Wade, 2012; Bufford et al., 2015, 2017; Emmons et al., 2017; Judd et al., 2020; Sytsma et al., 2018). However, these studies have not focused explicitly on Catholics and have not addressed the unique aspects of how Catholics experience grace. Thus, this study fills an important gap in the psychology of religion literature. Within this study, divine grace was understood as the extraordinary gift of redemption and forgiveness of sins from God offered to everyone who decides to acknowledge and accept it (Barclay, 2015; Emmons et al., 2017; McMinn et al., 2006). Humanity did not do anything to earn the gift of grace, and it cannot be earned. However, the gift of grace creates a bond of obligation and carries an expectation of obedience to God in return (Barclay, 2015).

The most critical theme in the study was tangible grace. These Catholics experienced divine grace not as a mysterious theological concept but as an embodied aspect of religious life that could be interacted with powerfully. The tangibility of God's grace within Catholic rituals and practices (e.g., the Eucharist, saints, confession, good works) appeared to make God's grace more objective and easier to interact with throughout the lifespan. One essential finding was that the sacrament of confession played a significant role in experiencing God's grace. The current study's findings are consistent with McKay et al. (2013), who found that confession promoted prosocial behavior, especially for individuals who believed in divine judgment and those who engaged in spiritual practices such as praying and reading Scripture.

Additionally, the results of the current study emphasized the importance of cooperating with God's grace freely through free will by engaging in good works. Theologians such as Barclay (2015) use the language of "obligation," though many in the study described interacting with God's grace as an opportunity that should be actively chosen daily. This distinction between freely participating with God's grace and having an obligation to engage with God's grace is important. This idea is also evident in a study by Warner et al. (2015) that examined the associations between making a charitable donation and duty to God, community expectations, and perceptions of God's grace among Catholic parish members. The interviews revealed that "God's grace and deservingness prompted thoughts of charity and... duty to God did not" (p. 204). Helping others was not considered a duty to God or a requirement of the faith; rather, it was considered a 
choice to "live as God tells them" (p. 200). Confession and good works were valuable and tangible means to experiencing God's grace. Similar to the study by Warner et al. (2015), these spiritual practices were often described not as obligations but as unique opportunities for Catholics to grow in their relationship with God.

\section{Limitations}

It is important to note the limitations of the study. First, the generalizability was limited by the participants' demographics. The majority of the participants were from Southern California $(82.76 \%)$ and identified as being White $(55.17 \%)$ or Hispanic or Latino (34.48\%). Catholics are relatively dispersed throughout the United States, with only $26 \%$ living in the West, and they come from a variety of ethnic backgrounds that differ from White and Hispanic or Latino (i.e., 3\% Asian, 3\% Black, 2\% mixed or Native American; Pew Research Center, 2015). Thus, these demographics do not demonstrate the cultural diversity of Catholics. Second, the inclusion criteria required participants to engage in their faith communities regularly (e.g., partaking in communion weekly; participating in confession annually). This inclusion criterion ensured that the participants were more religious and were able to thoroughly describe their religious and spiritual experiences using Catholic theology and terminology. However, it did not give voice to those who might be less involved in the church. Last, this study was conducted during the Covid-19 pandemic, which limited the participants' spiritual practices (e.g., they could not attend Mass, could not partake in the Eucharist or confession), and some indicated it impacted their spiritual and mental well-being.

Nonetheless, this study significantly contributes to the growing body of literature that explores and defines divine grace in the lives of Catholics. Understanding the role of divine grace in the Catholic faith is valuable as there are often misconceptions surrounding the Catholic understanding of grace and works. These findings support the need for further empirical exploration of divine grace, especially in the lives of Catholics.

Author Contribution All authors contributed to the study conception and design. The first draft of the manuscript was written by Hunter B. Harwood and all authors commented on previous versions of the manuscript. All authors read and approved the final manuscript.

Funding This work was supported by Grant 61304 from the John Templeton Foundation to Peter C. Hill, PI.

Data Availability Given ethical concerns, the interviews will not be made available. However, analyses can be requested from hunter.b.harwood@gmail.com.

\section{Declarations}

Ethics Approval Researchers received ethical approval from the institutional human rights in research committee at Biola University.

Consent to Participate All participants signed and completed an informed consent before the interviews.

Consent for Publication Data is anonymous and did not require special permission for publication.

Conflicts of Interest Researchers have no known conflicts of interest to disclose. 


\section{References}

Barclay, J. M. G. (2015). Paul and the gift. Eerdmans.

Bassett, R. L., \& Roberts Wesleyan College Psychology Research Group. (2013). An empirical consideration of grace and legalism within Christian experience. Journal of Psychology and Christianity, 32(1), 43-69.

Birt, L., Scott, S., Cavers, D., Campbell, C., \& Walter, F. (2016). Member checking: A tool to enhance trustworthiness or merely a nod to validation? Qualitative Health Research, 26(13), 1802-1811.

Blackburn, A. M., Sisemore, T. A., Smith, R. E., \& Re, D. (2012). Hope and forgiveness as mediators of enacted grace in Christians: A survey with implications for psychotherapy. Paper presented at the international conference of the Christians Association for Psychological Studies, Washington, DC.

Bronte, J. C., \& Wade, J. (2012). The experience of grace: Divine assistance in making a change. Journal of Transpersonal Psychology, 44(2), 182-200.

Bufford, R. K., Blackburn, A. M., Sisemore, T. A., \& Bassett, R. L. (2015). Preliminary analyses of three measures of grace: Can they be unified? Journal of Psychology and Theology, 43, 86-97.

Bufford, R. K., Sisemore, T. A., \& Blackburn, A. M. (2017). Dimensions of grace: Factor analysis of three grace scales. Psychology of Religion and Spirituality, 9(1), 56-69. https://doi.org/10.1037/ rel0000064

Catholic Church. (2000). Joint declaration on the doctrine of justification. W. B. Eerdmans.

Catholic Online. (n.d.). Stations of the cross-prayers. https://www.catholic.org/prayers/station.php. Accessed 12 Mar 2021.

Charmaz, K. (2014). Constructing grounded theory (2nd edn.). SAGE.

Council of Trent. (2019). In Encyclopaedia Britannica online. https://www.britannica.com/event/Council-of-Trent

Emmons, R. A., Hill, P. C., Barrett, J. L., \& Kapic, K. M. (2017). Psychological and theological reflections on grace and its relevance for science and practice. Psychology of Religion and Spirituality, 9(3), 276-284. https://doi.org/10.1037/rel0000136

Fischer, C. T. (2009). Bracketing in qualitative research: Conceptual and practical matters. Psychotherapy Research, 19(4-5), 583-590.

Fuliga, J. B. (2009). The role of good works in justification in post Vatican II's Catholic church. Asia Journal of Theology, 23(1), 123-135.

Godzieba, A. J. (2008). The Catholic sacramental imagination and the access/excess of grace. New Theology Review, 21(3), 14-26.

Judd, D. K., Dyer, W. J., \& Top, J. B. (2020). Grace, legalism, and mental health: Examining direct and mediating relationships. Psychology of Religion and Spirituality, 12(1), 26-35.

Landis, J. R., \& Koch, G. G. (1977). The measurement of observer agreement for categorical data. Biometrics, 33, 159-174.

Levitt, H. M., Bamberg, M., Creswell, J. W., Frost, D. M., Josselson, R., \& Suarez-Orozco, C. (2018). Journal article reporting standards for qualitative primary, qualitative, meta-analytic, and mixed methods research in psychology: The APA Publications and Communications Board task force report. American Psychologist, 73(1), 26-46.

McBrien, R. P. (1980). Catholicism (Vol. 2). Winston Press.

McHugh, J. A., \& Callan, C. J. (Trans.). (1923). Council of Trent Catechism for Parish Priests. Joseph F. Wagner, Inc.

McKay, R., Herold, J., \& Whitehouse, H. (2013). Catholic guilt? Recall of confession promotes prosocial behavior. Religion, Brain, \& Behavior, 3(3), 201-209.

McMinn, M. R., Ruiz, J. N., Marx, D., Wright, J. B., \& Gilbert, N. B. (2006). Professional psychology and the doctrines of sin and grace: Christian leaders' perspectives. Professional Psychology: Research and Practice, 37, 295-302. https://doi.org/10.1037/0735-7028.37.3.295

Payton, J. T., Spradlin, J. D., \& Bufford, R. K. (2000). A measure of grace: Preliminary development of a grace scale. Paper presented at the Christian Association for Psychological Studies annual meetings, Tulsa, OK.

Pew Research Center. (2015). America's changing religious landscape. Pew Research Center's Religion \& Public Life Project. https://www.pewforum.org/2015/05/12/americas-changing-religious-landscape/

Sisemore, T. A., Swanson, M., Arbuckle, M., Fisher, R., Lillian, M., McGinnis, J., \& Mortellaro, E. (2011). Grace and Christian psychology_Part 1: Preliminary measurement, relationships and implications for practice. Edification: The Transdisciplinary Journal of Christian Psychology, 4, 57-63.

Spradlin, J. D. (2002). Shame, grace, and spirituality: A Comparison of measures [Unpublished doctoral dissertation]. George Fox University.

Stjerna, K. I. (2015). Grace only? Or, all is grace? Dialog: A Journal of Theology, 54(3), 260-268. 
Sytsma, T. T., Schmelkin, L. A., Jenkins, S. M., Lovejoy, L. A., Lapid, M. I., \& Piderman, K. M. (2018). Keep the faith: Spirituality as a contributor to resiliency in five elderly people. Journal of Religion, Spirituality, \& Aging, 30(4), 314-324. https://doi.org/10.1080/15528030.2018.1441095

Vidovic, J. (2019). An orthodox perspective on the Joint Declaration on the Doctrine of Justification. The Ecumenical Review, 71(3), 280-295. https://doi.org/10.1111/erev.12428

Warner, C. M., Kılınç, R., Hale, C. W., Cohen, A. B., \& Johnson, K. A. (2015). Religion and public goods provision: Experimental and interview evidence from Catholicism and Islam in Europe. Comparative Politics, 47(2), 189-209.

Washburn, C. D. (2015). The transformative power of grace and condign merit at the Council of Trent. The Thomist: A Speculative Quarterly Review, 79(2), 173-212. https://doi.org/10.1353/tho.2015.0010

Watson, P. J., Chen, Z., \& Sisemore, T. A. (2011). Grace and Christian psychology-Part 2: Psychometric refinements and relationship with self-compassion, depression, beliefs about sin, and religious orientation. Edification: The Transdisciplinary Journal of Christian Psychology, 4(2), 64-72.

Publisher's Note Springer Nature remains neutral with regard to jurisdictional claims in published maps and institutional affiliations. 